\title{
Dinamika Produksi Daging Sapi di Pulau Jawa melalui Pendekatan Ekonometrik
}

\author{
(The Dynamics of Beef Production in Java Through Econometric Approach)
}

\author{
Priyono $^{1}$, Hapsari AAR ${ }^{2}$ \\ ${ }^{1}$ Pusat Penelitian dan Pengembangan Peternakan, Jl. Raya Pajajaran Kav. E-59, Bogor 16128 \\ ${ }^{2}$ Balai Penelitian Ternak, PO Box 221, Ciawi, Bogor 16002 \\ priyono.spt@gmail.com
}

\begin{abstract}
Java Island was the center of beef production, about $57.47 \%$ of national beef production. Beef production can be estimated by the cattle population of a region, but not in Java Island, where there was a dynamic changing between beef production and cattle population. The aim of this study was to analyze the dynamic of beef production in East, Central and West Java. This study was done by using time series data start on 2001 to 2016 with econometric approach. The region of this study was determined by purposive sampling. The econometric approach parameters used in this research were consists of beef production populations of cattle, beef production lag, and cattle population lag variables. The result of this study showed that on 2001-2016, the rate of beef production was reach $2.465 \%$ in East Java, $-0.022 \%$ in Central Java, and $0.349 \%$ in West Java. Beef production lag and cattle population lag significantly effected on beef production in East Java, meanwhile in Central Java the beef production was significantly affected by beef production lag. Comparative analysis result on beef production showed that there was significant beef production dynamic among the studied areas. West Java and Central Java have more complex production dynamic compared to East Java. Therefore, supply chain management needs to be considered to accelerate beef production.
\end{abstract}

Key Words: Beef Production, Java Island, Econometric Approach

\begin{abstract}
ABSTRAK
Pulau Jawa merupakan sentra produksi daging sapi dengan persentase $57,47 \%$ dari total produksi daging sapi nasional. Produksi daging sapi dapat diestimasi dari populasi sapi di suatu wilayah, namun tidak demikian di Pulau Jawa dimana terjadi dinamika antara produksi dan populasi sapi. Penelitian ini bertujuan untuk menelaah dinamika produksi daging sapi di Provinsi Jawa Timur, Jawa Tengah dan Jawa Barat. Penelitian dilakukan dengan menggunakan data time series mulai tahun 2001 sampai dengan 2016 menggunakan pendekatan ekonometrik. Wilayah penelitian ditentukan dengan purposive sampling. Parameter yang digunakan dengan pendekatan ekonometrik terdiri dari variabel produksi daging sapi, populasi sapi, lag produksi daging sapi dan lag populasi sapi. Hasil penelitian menunjukkan bahwa pada tahun 2001-2016, laju pertumbuhan produksi daging sebesar 2,465\% di Jawa Timur, $-0,022 \%$ di Jawa Tengah dan 0,349\% di Jawa Barat. Lag produksi daging sapi dan lag populasi sapi potong berpengaruh nyata terhadap jumlah produksi daging di Jawa Timur, sedangkan produksi daging sapi di Jawa Tengah dipengaruhi secara nyata oleh lag produksi daging sapi. Hasil analisis komparasi produksi daging menunjukkan terjadi dinamika produksi yang nyata antar ketiga wilayah yang diteliti. Jawa Barat dan Jawa Tengah memiliki dinamika produksi daging yang lebih kompleks dibandingkan dengan Jawa timur. Dengan demikian, manajemen rantai pasok sapi di Pulau Jawa perlu diperhatikan untuk mengakselerasi produksi daging sapi.
\end{abstract}

Kata Kunci: Produksi Daging Sapi, Pulau Jawa, Pendekatan Ekonometrik 


\section{PENDAHULUAN}

Di wilayah Pulau Jawa, khususnya Provinsi Jawa Timur, Jawa Tengah dan Jawa Barat merupakan daerah sentra produksi daging tertinggi nasional, meskipun daerah tersebut memiliki kepadatan penduduk tertinggi dibandingkan dengan wilayah lain di luar Pulau Jawa. Berbagai kebijakan dan program telah dilakukan pemerintah dalam upaya untuk mencapai swasembada daging sapi. Program-program tersebut ditujukan untuk meningkatkan populasi sapi yang akan berdampak pada peningkatan ketersediaan daging sapi nasional.

Secara nasional, Pulau Jawa merupakan sentra pemasok sapi potong dengan persentase populasi sapi potong sebesar $43,44 \%$ dari total populasi sapi potong nasional pada tahun 2015. Sementara itu pada tahun yang sama Pulau Jawa juga memegang kendali atas produksi daging sapi nasional sebesar 57,47\% dari total produksi daging nasional (BPS 2016). Jumlah populasi sapi potong dapat digunakan sebagai pendekatan untuk mengetahui kemampuan produksi daging sapi yang dapat dihasilkan.

Populasi sapi di Provinsi Jawa Timur sebanyak 4,267 juta ekor (27,67\% dari total nasional) pada tahun 2015 mampu menghasilkan produksi daging sapi sebanyak 95.431 ton $(18,84 \%)$. Sedangkan Provinsi Jawa Tengah dengan populasi sapi sebanyak 1,642 juta ekor $(10,65 \%$ dari total nasional) mampu menghasilkan produksi daging sapi sebanyak 55.332 ton $(10,92 \%)$. Sementara itu, Provinsi Jawa Barat dengan populasi sapi sebanyak 0,425 juta ekor $(2,76 \%)$, justru mampu menghasilkan produksi daging sapi sebesar 75.478 ton $(14,90 \%)$ (Ditjen PKH 2016). Hal ini menunjukkan terjadi dinamika produksi daging sapi terutama di Pulau Jawa. Dinamika produksi daging sapi ini dapat dianalisis dengan menggunakan pendekatan ekonometrik.

Pendekatan ekonometrik dapat digunakan untuk menganalisis pertumbuhan dan menganalisis faktor-faktor yang mempengaruhi produksi daging sapi dan komparasi antar wilayah. Berdasarkan kondisi tersebut diperlukan analisis pertumbuhan dan dinamika produksi daging sapi di Provinsi Jawa Timur, Jawa Tengah dan Jawa Barat.

Penelitian ini bertujuan untuk menelaah dinamika produksi daging sapi di Provinsi Jawa Timur, Jawa Tengah dan Jawa Barat sebagai sentra produksi daging sapi di Indonesia. Hasil penelitian ini diharapkan dapat dijadikan sebagai masukan dalam penyusunan rekomendasi kebijakan akselerasi pemenuhan produksi daging sapi di Pulau Jawa.

\section{MATERI DAN METODE}

\section{Metode penelitian}

Penelitian dilakukan dengan menggunakan data time series mulai tahun 2001 sampai dengan 2016 menggunakan pendekatan ekonometrik. Wilayah penelitian ditentukan secara purposive (sengaja) dengan pertimbangan bahwa Provinsi Jawa Timur, Jawa Barat dan Jawa Tengah secara berturut-turut memiliki peringkat produksi daging sapi ke- 1, 2 dan 3 nasional. Teknik purposive sampling merupakan teknik penentuan sampel dengan pertimbangan tertentu sesuai dengan tujuan yang dikehendaki (Sugiyono 2011). Sumber data berasal dari data sekunder yang diperoleh dari Badan Pusat Statistik (BPS) dan Direktorat Jenderal Peternakan dan Kesehatan Hewan (Ditjen PKH), Kementerian Pertanian. Parameter yang digunakan dalam pendekatan ekonometrik terdiri dari variabel produksi daging sapi sebagai variabel terikat dan variabel bebasnya terdiri dari populasi sapi, lag produksi daging sapi dan lag populasi sapi yang dianalisis pada masing-masing wilayah yang diteliti. 


\section{Metode analisis}

Dinamika produksi daging sapi di tiga wilayah yang telah ditentukan dianalisis dengan pendekatan ekonometrik. Model yang digunakan merupakan model regresi linier berganda dengan satu variabel terikat dan tiga variabel bebas. Model regresi linier berganda yang digunakan yaitu:

$$
\begin{array}{ll}
\qquad & \multicolumn{1}{c}{\mathrm{Y}=\mathrm{a}+\mathrm{b}_{1} \mathrm{X}_{1}+\mathrm{b}_{2} \operatorname{LagY}+\mathrm{b}_{3} \operatorname{Lag} \mathrm{X}_{1}+\varepsilon} \\
\mathrm{Y} & =\text { Produksi daging sapi (ton) } \\
\mathrm{X} 1 & =\text { Populasi sapi potong (ribu ekor) } \\
\operatorname{LagY} & =\text { Produksi daging sapi tahun sebelumnya (ton) } \\
\mathrm{LagX}_{1} & =\text { Populasi sapi potong tahun sebelumnya (ribu ekor) } \\
\varepsilon & =\text { Galat/eror }
\end{array}
$$

Perbedaan dinamika produksi daging sapi antar wilayah Provinsi Jawa Timur, Jawa Tengah dan Jawa Barat diuji komparasi dengan uji t berpasangan (Walpole 1995). Uji t berpasangan harus memenuhi asumsi data terdistribusi normal, oleh karena itu dilakukan uji normalitas data menggunakan uji Kolmogorov-Smirnov. Uji komparasi ini untuk mengetahui produksi daging sapi di Pulau Jawa relatif sama atau berbeda. Jika dinamikanya berbeda maka dapat ditentukan kebijakan yang tepat terkait dengan kondisi tersebut.

\section{HASIL DAN PEMBAHASAN}

\section{Analisis pertumbuhan produksi daging sapi}

Kebijakan pengembangan ternak sapi perlu memperhatikan dinamika yang ada pada masing-masing daerah. Jawa Timur, Jawa Tengah dan Jawa Barat merupakan tiga daerah dengan jumlah produksi daging tertinggi secara nasional. Ketiga daerah ini memiliki kontribusi sebesar 44,65\% daging sapi secara nasional. Adapun pertumbuhan produksi daging sapi pada ketiga provinsi tersebut juga menunjukkan perbedaan. Pertumbuhan produksi daging sapi pada tahun 2001-2016 di Jawa Timur sebesar 2,465\%, Provinsi Jawa Tengah sebesar -0,022\% dan Provinsi Jawa Barat sebesar 0,349\%.

Jawa Timur memiliki grafik pertumbuhan produksi daging sapi yang meningkat, namun kemudian bergerak menurun pada tahun 2013 (Gambar 1). Nilai pertumbuhan produksi daging sapi di Jawa Timur paling tinggi dibandingkan dengan di Jawa Tengah dan Jawa Barat. Menurut Winarso et al. (2005) Jawa Timur merupakan salah satu provinsi yang sangat potensial untuk pengembangan sapi potong, namun masih dihadapkan pada beberapa kendala diantaranya adanya alih fungsi lahan pertanian, belum maksimalnya keberhasilan intensifikasi ternak melalui IB dan masih diperlukannya upaya kebijakan yang mengarah pada ekstensifikasi ternak potong. Hal ini sesuai Hasan (2009) bahwa trend produksi daging di Jawa Timur secara umum meningkat, meskipun terdapat penurunan tajam pada tahun 1998-1999, namun mulai tahun 2001-2007 mengalami pertumbuhan yang positif. Adapun Jawa Barat memiliki grafik perkembangan peningkatan yang tidak terlalu signifikan, bahkan cenderung stagnan. Namun daerah ini masih memiliki pertumbuhan produksi daging sapi yang nilainya positif yakni sebesar 0,349\%. Berbeda dengan Jawa Timur dan Jawa Barat, Provinsi Jawa Tengah memiliki grafik pertumbuhan yang nilainya negatif sebesar $-0,022 \%$. 


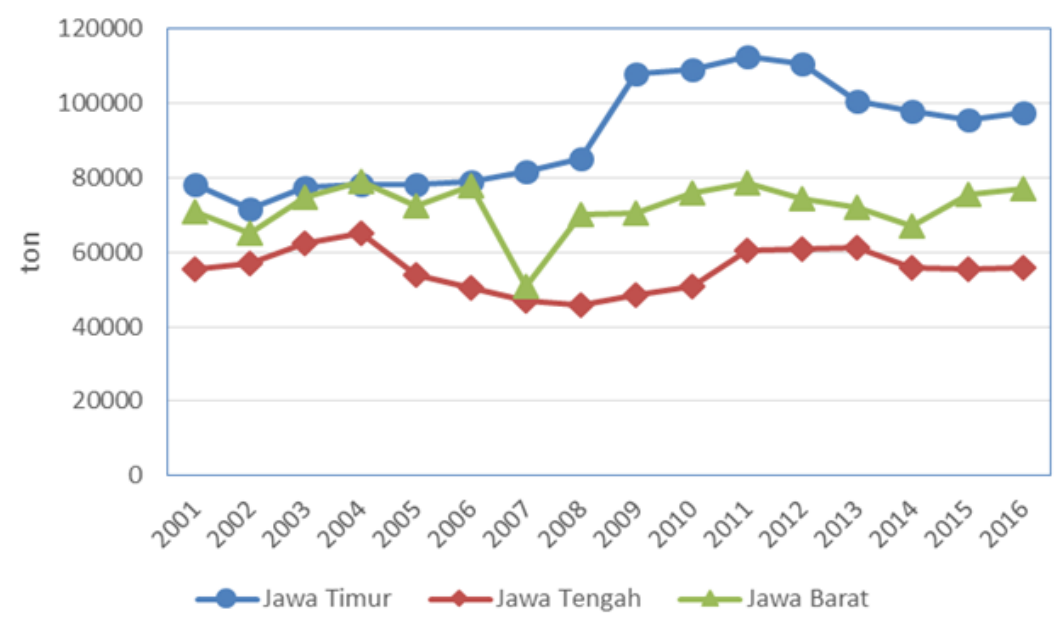

Gambar 1. Perkembangan produksi daging sapi di Jawa Timur, Jawa Tengah dan Jawa Barat tahun 2001-2016 (ton)

Sumber: Data Ditjen PKH dan BPS diolah (2016)

Besaran produksi daging sapi pada suatu daerah erat kaitannya dengan jumlah populasi sapi potong yang ada pada daerah tersebut. Matondang \& Rusdiana (2014) menyatakan bahwa untuk meningkatkan populasi sapi potong investasi dan langkah terobosan yang belum dilakukan pada sapi potong tapi telah berhasil untuk komoditas lain, misalnya konsesi penggunaan lahan untuk peternakan. Jawa Timur, Jawa Tengah dan Jawa Barat meskipun memiliki kontribusi produksi daging sapi sebesar 44,65\%, namun ketiga daerah ini memiliki kontribusi populasi sapi potong yang lebih rendah dibandingkan produksinya yaitu sebesar $41,08 \%$ dari total populasi sapi potong nasional. Perkembangan populasi sapi tahun 2001-2016 untuk Jawa Timur, Jawa Tengah dan Jawa Barat disajikan pada Gambar 2.

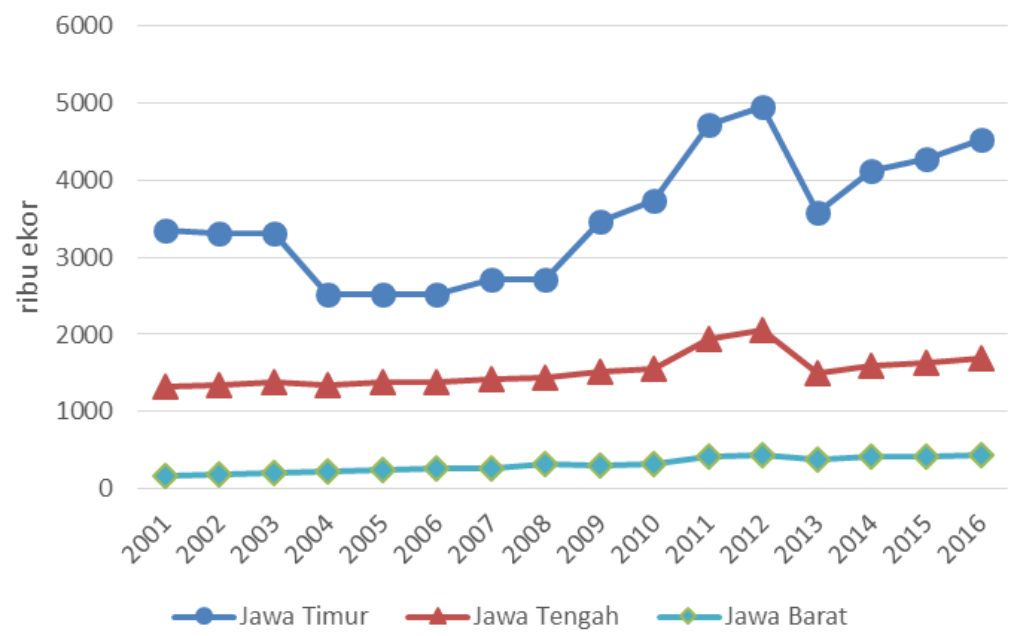

Gambar 2. Perkembangan populasi ternak sapi potong di Jawa Timur, Jawa Tengah dan Jawa Barat tahun 2001-2016 (ribu ekor)

Sumber: Data Ditjen PKH dan BPSdiolah (2016)

Berdasarkan perkembangan populasi ternak sapi potong di tiga wilayah (Gambar 2) diketahui bahwa Jawa Timur memiliki grafik pertumbuhan yang meningkat secara signifikan mulai tahun 2005, namun mengalami penurunan yang signifikan pada tahun 2013. Berdasarkan kondisi di atas, Jawa Barat memiliki populasi sapi yang lebih kecil 
dibandingkan dengan Jawa Timur dan Jawa Tengah, namun memiliki produksi daging yang relatif lebih tinggi dibandingkan dengan Jawa Tengah. Hal ini diduga disebabkan Jawa Barat mendapatkan pemasukan ternak sapi dari luar daerah sehingga produksi daging sapi yang dihasilkan tidak sebanding dengan populasi ternak sapi yang ada. Menurut Adinata et al. (2012) untuk mengembangkan populasi sapi potong dapat dilakukan melalui pengoptimalan dan pengembangan kemampuan internal peternak, pemanfaatan sumberdaya alam yang tersedia, pengenalan teknologi pengolahan pakan berbasis limbah, penggunaan bibit unggul dan menjalin usaha kemitraan.

\section{Dinamika produksi daging sapi}

Hasil analisis regresi linier berganda menunjukkan bahwa produksi daging sapi di Jawa Timur dan Jawa Tengah dipengaruhi $(\mathrm{P}<0,05)$ oleh variabel bebas dalam model penelitian ini, sedangkan produksi daging sapi di Jawa Barat tidak dipengaruhi secara nyata $(\mathrm{P}>0,05)$ oleh variabel bebas.

Tabel 1. Hasil analisis regresi linier berganda

\begin{tabular}{lcccccc}
\hline \hline \multirow{2}{*}{ Peubah } & \multicolumn{2}{c}{$\begin{array}{c}\text { Provinsi Jawa Timur } \\
\left(\mathrm{R}^{2}=0,846 ; \mathrm{Sig}=0,000\right)\end{array}$} & \multicolumn{2}{c}{$\begin{array}{c}\text { Provinsi Jawa Tengah } \\
\left(\mathrm{R}^{2}=0,551 ; \mathrm{Sig}=0,019\right)\end{array}$} & \multicolumn{2}{c}{$\begin{array}{c}\text { Provinsi Jawa Barat } \\
\left(\mathrm{R}^{2}=0,295 ; \mathrm{Sig}=0,768\right)\end{array}$} \\
\cline { 2 - 7 } & Koefisien & Sig. & Koefisien & Sig. & Koefisien & Sig. \\
\hline $\begin{array}{l}\text { Populasi sapi } \\
\text { potong (X) }\end{array}$ & 0,259 & 0,093 & 0,191 & 0,413 & 0,354 & 0,372 \\
$\begin{array}{l}\text { Lag produksi } \\
\text { daging sapi (Y) }\end{array}$ & 0,919 & 0,001 & 0,712 & 0,004 & 0,011 & 0,971 \\
$\begin{array}{l}\text { Lag populasi } \\
\text { sapi potong }\left(\mathrm{X}_{1}\right)\end{array}$ & $-0,327$ & 0,034 & 0,002 & 0,994 & $-0,287$ & 0,453 \\
\hline
\end{tabular}

Y: Produksi daging sapi

Sumber: Data diolah (2016)

Koefisien determinasi model produksi daging sapi di Jawa Timur sebesar 0,846 (Tabel 1). Nilai tersebut menunjukkan bahwa $84,6 \%$ produksi daging sapi Jawa Timur dipengaruhi oleh populasi, lag populasi dan lag produksi daging sapi, sedangkan $15,4 \%$ produksi daging sapi Jawa Timur dipengaruhi oleh variabel bebas lain di luar model. Nilai koefisien determinasi $\left(\mathrm{R}^{2}\right)$ Jawa Tengah sebesar 0,551 menunjukkan bahwa sebesar 55,1\% produksi daging sapi Jawa Tengah dipengaruhi oleh populasi, lag populasi dan lag produksi daging sapi dalam model penelitian ini, sedangkan sisanya $44,9 \%$ produksi daging sapi Jawa Tengah dipengaruhi oleh variabel bebas lain di luar model. Berbeda dengan Jawa Timur dan Jawa Tengah, Provinsi Jawa Barat tidak dipengaruhi secara nyata oleh variabel bebas yang digunakan dalam model yang ditunjukkan dengan nilai probabilitas kesalahan 76,8\%.

Di Jawa Timur, koefisien regresi lag produksi daging sapi sebesar 0,919 dengan signifikansi 0,001 menunjukkan bahwa jika produksi daging sapi pada tahun sebelumnya mengalami peningkatan sebesar 1 satuan, maka produksi daging sapi pada tahun berikutnya akan meningkat 0,9 kali. Disamping itu, lag populasi sapi potong juga berpengaruh nyata terhadap produksi daging sapi di Jawa Timur $(\mathrm{P}<0,05)$. Hasil analisis menunjukkan bahwa koefisien regresi sebesar -0,327 dengan signifikansi sebesar 0,034 menunjukkan bahwa jika saat ada peningkatan populasi sapi potong pada tahun sebelumnya di Jawa Timur, akan berdampak pada penurunan produksi daging sapi. 
Dinamika ini dapat terjadi diduga akibat adanya pengeluaran ternak hidup untuk dipotong diluar daerah Jawa Timur. Berdasarkan potensi pasar domestik, usaha ternak penghasil daging khususnya sapi memiliki peluang yang besar untuk dikembangkan (Kusnadi 2008).

Sementara itu, di Jawa Tengah koefisien regresi sebesar 0,712 dengan signifikansi sebesar 0,04 menunjukkan bahwa jika produksi daging sapi tahun sebelumnya di Jawa Tengah meningkat jumlahnya, maka produksi daging sapi di Jawa Tengah akan meningkat. Upaya peningkatan produksi daging sapi di Jawa Tengah dapat dilakukan melalui kebijakan-kebijakan yang mendukung pengembangan usaha sapi potong di Jawa Tengah. Menurut Tawaf \& Arief (2011) ketersediaan produksi daging sapi sangat ditentukan oleh tiga kritikal poin, yaitu pada tingkat pasokan (peternak), tingkat logistik (RPH) dan distribusi daging sapi (importasi daging dan jeroan).

Berbeda dengan dinamika produksi daging sapi di Jawa Timur dan Jawa Tengah, pada wilayah Provinsi Jawa Barat produksi daging sapi baik secara serempak maupun secara parsial tidak dipengaruhi secara nyata oleh variabel yang digunakan dalam model $(\mathrm{P}>0,10)$. Tidak berpengaruhnya variabel bebas dalam model ini diduga disebabkan karena wilayah Jawa Barat merupakan wilayah yang banyak menampung sapi hidup dari luar daerah untuk dipotong di RPH di sekitar wilayah Bekasi, Depok, Bogor dan Bandung. Hal ini ditunjukkan dengan jumlah populasi sapi potong di Jawa Barat pada tahun 2015 sebesar 425.826 ekor (Gambar 2), produksi daging sapinya mencapai 75.478 ton (Gambar 1).

Berdasarkan hal ini, diduga Provinsi Jawa Barat banyak mendapatkan pemasukan ternak sapi dari luar daerah terutama Jawa Tengah yang jumlah populasi sapinya lebih tinggi dari Jawa Barat namun produksi daging sapinya lebih rendah dari Jawa Barat. Hal ini sesuai dengan Priyanti et al. (2011) bahwa faktor-faktor yang mempengaruhi peningkatan populasi dan produksi daging sapi bervariasi antar wilayah, sebagian besar merupakan faktor pemasukan dan pengeluaran sapi. Hal yang menarik dari hasil uji ini adalah di ketiga lokasi ini produksi daging sapi tidak dipengaruhi oleh populasi sapi pada waktu tersebut namun dipengaruhi kondisi di tahun sebelumnya. Beragamnya dinamika produksi daging sapi di Jawa Timur, Jawa Tengah dan Jawa Barat perlu didukung oleh kebijakan peningkatan produksi daging sapi sesuai dengan spesifik lokasi. Jika dilihat dari hasil pendekatan ekonometrik, kebijakan peningkatan populasi sapi merupakan pendekatan untuk mengakselerasi peningkatan produksi daging sapi. Menurut Harmini et al. (2011), untuk mempercepat pencapaian kecukupan daging sapi nasional diperlukan intervensi dalam pengurangan pemotongan sapi lokal betina produktif secara bertahap dan peningkatan secara bertahap program kawin silang sapi lokal dengan inseminasi buatan. Akselerasi peningkatan populasi sapi dapat dilakukan melalui berbagai program yang mendukung usaha peternak sapi baik dari aspek teknis, ekonomis, sampai dengan pasar.

Uji t berpasangan harus memenuhi asumsi data terdistribusi normal, oleh karena itu dilakukan uji normalitas data menggunakan uji Kolmogorov-Smirnov. Berdasarkan hasil pengujian diperoleh bahwa data produksi daging sapi di Jawa Timur memiliki signifikansi sebesar 0,360 ( $\mathrm{P}>0,05)$ menunjukkan hasil uji tidak signifikan, sehingga data produksi daging di Jawa Timur terdistribusi normal. Uji sebaran normal pada Provinsi Jawa Tengah dan Jawa Barat juga menunjukkan hal yang sama dimana masing-masing memiliki signifikansi 0,905 $(\mathrm{P}>0,05)$ dan 0,526 $(\mathrm{P}>0,05)$ artinya hasil uji keduanya tidak signifikan. Hal ini menunjukkan bahwa uji komparasi produksi daging sapi di Jawa Timur, Jawa Tengah dan Jawa Barat menggunakan uji t berpasangan dinyatakan memenuhi syarat secara statistik. Hasil analisis komparasi produksi daging sapi dengan menggunakan uji $t$ berpasangan disajikan pada Tabel 2 . 
Tabel 2. Hasil uji t berpasangan

\begin{tabular}{lcc}
\hline \hline Jenis uji beda & Nilai thitung & Sig. \\
\hline $\begin{array}{l}\text { Komparasi produksi daging sapi Provinsi Jawa Timur dengan } \\
\text { Provinsi Jawa Tengah }\end{array}$ & 9,550 & 0,000 \\
$\begin{array}{l}\text { Komparasi produksi daging sapi Provinsi Jawa Timur dengan } \\
\text { Provinsi Jawa Barat }\end{array}$ & 5,553 & 0,001 \\
$\begin{array}{l}\text { Komparasi produksi daging sapi Provinsi Jawa Tengah dengan } \\
\text { Provinsi Jawa Barat }\end{array}$ & $-10,045$ & 0,000 \\
\hline
\end{tabular}

Sumber: Data diolah (2016)

Hasil uji t berpasangan menunjukkan bahwa produksi daging sapi di Jawa Timur dengan Jawa Tengah berbeda nyata dengan nilai $t$ hitung sebesar 9,550 $(\mathrm{P}<0,05)$. Perkembangan produksi daging sapi Jawa Timur dari tahun 2001-2016 sebesar 2,465\% per tahun menunjukkan perkembangan yang relatif lebih tinggi dibandingkan dengan perkembangan produksi daging sapi di Jawa Tengah yang sebesar $-0,022 \%$ per tahun. Menurut Mukson et al. (2014), untuk meningkatkan produksi daging sapi perlu terus diupayakan peningkatan populasi sapi potong, peningkatan produksi daging selain ternak sapi, pengendalian jumlah penduduk, pengeluaran ternak sapi ke daerah lain dan kapasitas pemotongan di RPH.

Sementara itu, komparasi produksi daging sapi antara Provinsi Jawa Timur dengan Jawa Barat berdasarkan hasil analisis uji t berpasangan menunjukkan perbedaan yang nyata dengan nilai t hitung sebesar 5,553 $(\mathrm{P}<0,05)$. Perkembangan produksi daging sapi di Jawa Barat menunjukkan nilai yang positif sebesar 0,349\% per tahun mulai tahun 20012016. Berdasarkan jumlah populasi ternak sapi pada tahun 2015, populasi sapi di Jawa Timur mencapai 11,16 kali dari populasi sapi di Jawa Barat, namun produksi dagingnya hanya 1,27 kali dari produksi daging sapi di Jawa Barat.

Nilai t hitung antara produksi daging sapi di Jawa Tengah dan Jawa Barat sebesar 10,045 $(\mathrm{P}<0,05)$, menunjukkan bahwa terdapat perbedaan yang nyata antara produksi daging sapi pada kedua wilayah tersebut. Pada tahun 2015, Jawa Tengah memiliki populasi sapi sebanyak 4,8 kali dari populasi sapi di Jawa Barat, namun produksi dagingnya lebih rendah dibandingkan dengan produksi daging sapi di Jawa Barat. Diduga, di Jawa Tengah terdapat pengeluaran sapi ke luar daerah terutama untuk dipotong di wilayah Jawa Barat yang berbatasan langsung dengan ibukota negara. Pemotongan sapi yang dilakukan di wilayah Jawa Barat akan memberikan nilai tambah berupa harga jual daging sapi yang relatif lebih kompetitif dibandingkan dengan yang dijual di daerah.

Menurut Emhar et al. (2014), proses pemotongan sapi hidup menjadi daging sapi sebagai produk utama dan karkas lain sebagai produk samping mampu menghasilkan nilai tambah rata-rata sebesar Rp. 33.144,68/kg atau 36,24\% dari total output yang dihasilkan. Lebih lanjut menurut Izzaty (2013), peningkatan harga daging sapi terjadi akibat terjadinya ketidakseimbangan permintaan dan penawaran serta pengaruh kebijakan penurunan kuota impor secara bertahap, oleh karena itu diperlukan transparansi dalam mekanisme impor dan memperkuat produksi domestik. Produksi daging sapi pada tahun 2015 di Jawa Tengah sebesar 55.332 ton, sedangkan produksi daging di Jawa Barat sebesar 75.478 ton (BPS 2016). Hal ini menunjukkan bahwa Provinsi Jawa Barat dan Jawa Tengah merupakan daerah yang memiliki dinamika yang lebih kompleks dalam produksi daging. 


\section{KESIMPULAN}

Laju peningkatan produksi daging sapi tahun 2001-2016 di Provinsi Jawa Timur sebesar 2,465\%, Provinsi Jawa Tengah sebesar -0,022\% dan Provinsi Jawa Barat sebesar $0,349 \%$. Produksi daging sapi di Jawa Timur dipengaruhi secara nyata oleh lag produksi daging sapi dan lag populasi sapi potong. Sementara itu, produksi daging sapi di Jawa Tengah secara nyata dipengaruhi oleh lag produksi daging sapi. Hasil analisis komparasi menunjukkan bahwa ketiga wilayah memiliki perbedaan dinamika produksi daging sapi yang nyata. Jawa Barat dan Jawa Tengah memiliki dinamika produksi daging sapi yang lebih kompleks dibandingkan dengan Jawa timur. Wilayah Jawa Barat dengan populasi sapi yang lebih rendah dibandingkan dengan Jawa Tengah, namun memiliki produksi daging sapi yang lebih tinggi dibandingkan dengan Jawa Tengah.

\section{UCAPAN TERIMA KASIH}

Penulis mengucapkan terima kasih kepada Badan Pusat Statistik (BPS) dan Direktorat Jenderal Peternakan dan Kesehatan Hewan, Kementerian Pertanian terkait penggunaan data sekunder dalam penelitian ini. Penulis juga berterimakasih pada Prof. Dr. Ir. Endang Tri Margawati, MSc.Agr., Peneliti Utama dari Puslit Bioteknologi LIPI atas bimbingannya dalam penyelesaian tulisan ini.

\section{DAFTAR PUSTAKA}

Adinata KI, Sari AI, Rahayu ET. 2012. Strategi pengembangan usaha sapi potong di Kecamatan Mojolaban Kabupaten Sukoharjo. Trop Anim Husb. 1:24-32.

BPS. 2016. Statistik Indonesia 2015. Indonesia (Jakarta): Badan Pusat Statistik.

Ditjen PKH. 2016. Statistik peternakan 2016. Jakarta (Indonesia): Direktorat Jenderal Peternakan dan Kesehatan Hewan.

Emhar A, Aji JMM, Agustina T. 2014. Analisis rantai pasokan (supply chain) daging sapi di Kabupaten Jember. Berkala Ilmiah Pertanian. 1:53-61.

Harmini, Asmarantaka RW, Atmakusuma J. 2011. Model dinamis sistem ketersediaan daging sapi nasional. J Ekonomi Pembangunan. 12:128-146.

Hasan F. 2009. Kinerja peternakan Jawa Timur di otonomi daerah. Embryo. 6:133-139.

Izzaty. 2013. Upaya stabilisasi harga daging sapi. Info Singkat Ekonomi dan Kebijakan Publik. 5:13-16.

Kusnadi U. 2008. Inovasi teknologi peternakan dalam sistem integrasi tanaman-ternak untuk menunjang swasembada daging sapi. Pengembangan Inovasi Pertanian. 1:189-205.

Matondang RH, Rusdiana S. 2014. Langkah-langkah strategis dalam mencapai swasembada daging sapi/kerbau 2014. J Litbang Pertanian. 32:131-139.

Mukson, Roessali W, Setiyawan H. 2014. Analisis wilayah pengembangan sapi potong dalam mendukung swasembada daging di Jawa Tengah. J Peternakan Indonesia. 16:26-32.

Priyanti A, Mahendri IGAP, Kusnadi U. 2011. Dinamika produksi daging sapi di wilayah sentra usaha sapi potong di Indonesia. Dalam: Prosiding Seminar Nasional Petani dan Pembangunan Pertanian. Bogor, 12 Oktober 2011. Bogor (Indonesia): Pusat Sosial Ekonomi dam Kebijakan Pertanian. hlm. 573-589.

Sugiyono. 2011. Metode penelitian pendidikan (pendekatan kualitatif, kuantitatif dan R\&D). Bandung (Indonesia): Alfabeta. 
Tawaf R, Arief H. 2011. Strategi pendekatan ketersediaan daging nasional di Indonesia. Dalam: Prosiding Seminar Nasional Peternakan Berkelanjutan III. Jatinangor, 2 November 2011. Jatinangor (Indonesia): Fakultas Peternakan Universitas Padjajaran. hlm. 1-6.

Walpole RE. 1995. Pengantar statistika. Jakarta (Indonesia): Gramedia Pustaka Utama.

Winarso B, Sajuti R, Muslim C. 2005. Tinjauan ekonomi ternak sapi potong di Jawa Timur. Forum Penelitian Agro Ekonomi. 23:61-71.

\section{DISKUSI}

\section{Pertanyaan}

Peningkatan populasi di Jawa Timur lebih tinggi dibandingkan dengan Jawa Tengah dan Jawa Barat namun produksi daging lebih tinggi, apa yang mempengaruhi hal tersebut?

\section{Jawaban}

Populasi sapi yang tinggi sama atau linier dengan penghasil daging sapi tertinggi, seperti terjadi di Jawa Timur. Di Jawa Barat tidak linier karena mungkin sapi dari Jawa Tengah dibawa dan dipotong di Jawa Barat. Dari hasil analisis Jawa Barat mendapat masukan ternak sapi dari luar daerah untuk dipotong. 